\title{
Isparta Kent Merkezindeki Apartman Bahçelerinin İrdelenmesi Üzerine Bir Araştırma
}

\author{
Candan KUŞ ŞAHIN ${ }^{1 *}$, M. Atilla AŞKIN ${ }^{2}$ \\ ${ }^{1}$ Süleyman Demirel Üniversitesi, Mimarlık Fakültesi, Peyzaj Mimarlığı Bölümü,32260, ISPARTA \\ ${ }^{2}$ Lefke Avrupa Üniversitesi, Tarım Bilimleri ve Teknolojileri Fakültesi, LEFKE, KKTC
}

\section{Öz}

Hızla artan nüfus ve kırsal kesimlerden şehir merkezlerine olan göçün etkisi sonucu kentin geleneksel konut dokusunun yetersiz kalmasıyla, kentlerde genel olarak gecekondu, halk konutları, şehir içi bitişik-düzen apartman, şehir içi site ve uydu kent siteleri biçiminde tanımlanan konut alanları ortaya çıkmıştır. Apartman bölgeleri, nüfus artışı ve kentin genişlemesine bağlı olarak kenar boş alanlar üzerinde veya merkezdeki gecekondu alanlarında yapılmaya başlanmıştır. Konut ve çevre standartlarına göre farklılaşan apartman çevreleri, çoğunlukla toplumun orta ve alt bütün kesimlerini barındırmaktadır. İnsanların barınma ihtiyaçlarının karşılanması yanında sosyolojik yönden önemli ihtiyaçların karşılanmasına yardımcı olan konut bahçeleri, kentsel açık yeşil alan birimlerinden birisi olarak kabul edilmektedir. Bu bağlamda yapılan çalışmada, Isparta kent merkezindeki apartman bahçelerinde kullanılan bitkisel materyallerin tespiti ve bahçelerin mevcut durumlarının ortaya konulması amaçlanmıştır. $\mathrm{Bu}$ bağlamda araştırmada, Isparta kent merkezindeki apartmanlarda bahçe ile ilgilenen kişilere anket uygulanmıştır. Isparta kent merkezindeki 32 mahallede rastgele örnekleme yöntemi ile belirlenen apartman bahçelerinin kullanım amaç ve şekilleri ile bakım koşullarının nitel ve nicel yöntemler yardımıyla ortaya konulması amaçlanmıştır. Apartman bahçelerinde tespit edilen bitkisel materyallerin yoğunluğu, kullanım amaçları ve bitkisel tasarım yönünden değerlendirilmeleri yapılarak çalışma sonuçlandırılmıştır.

Anahtar Kelimeler: Isparta, apartman, bahçe, bitkisel materyal.

\section{A Study on Investigation of Apartment Gardens in Isparta City Center}

\begin{abstract}
As a result of the rapidly increasing population and the effect of the migration from rural areas to the city centers, the city's traditional housing texture was remained inadequate, resulting in creating shanty houses, public housing, inner city adjoining-order apartments and satellite towns. However, depending on the population and the expansion of the cities, the housing structures have become to build with very close margins and together within slums. On the other hand, apartments and their near environments, which differ according to housing and standards, mostly accommodate all middle and middle sub-sections of the society. Besides meet people's accommodation needs, home gardens are considered as one of the urban open green space units and to meet the sociologically important needs for people. In this study, it is aimed to determine the plant materials used in apartment's gardens in Isparta city center and to reveal the current status of the gardens. In this context, a questionnaire was applied to the people who are interested in the garden in the apartments in 32 neighborhoods of Isparta city center. Hence, it is aimed to determine the primarily use conditions of multi storey apartment's gardens with random sampling method. The qualitative and quantitative approaches have been conducted to determine plant materials that their identifications, intensity, intended use within evaluations was made in terms of plant design practices.
\end{abstract}

Keywords: Isparta city, apartment, garden, plant material.

\footnotetext{
*Sorumlu Yazar (Corresponding Author): 


\section{Giriş}

Kentler, devamlı toplumsal gelişme içinde bulunan ve toplumun barınma, yerleşme, çalışma, dinlenme, eğlenme gibi gereksinimlerinin karşılandığı, köylere göre nüfus yönünden daha yoğun olan yerleşme birimleridir (Keleş, 1980). Kent tanımında önemli bir kriter olan nüfus yoğunluğu, barınma sorununu da beraberinde getirmektedir. Zamanla barınma; göçler, nüfus artı̧̧, hızlı kentleşme vb faktörler nedeniyle çözümü giderek güçleşen sorunlar arasında yer almış ve bunun sonucunda konut açığı ortaya çıkmıştır.

Barınma ihtiyacının bir sonucu olarak ortaya çıkan konut, ilk olarak tekil ve tek katlı yapı biçiminde yatayda gelişmiştir. Ancak zamanla toplumların kültürel, ekonomik, sosyal ve teknik alanlardaki gelişmeleri doğrultusunda konut ihtiyacının artması ve konut arazilerin yetersiz kalması nedeniyle düşeyde gelişim göstermeye başlamıştır. Aydınlanma Çağı'nın sonucunda Avrupa'da Sanayi Devrimi'nin gerçekleşmesiyle birlikte endüstrinin bulunduğu kentlere göç eden işçi sınıfın barınma ihtiyacını karşılamak adına yapılan ve o dönem işçi konutları adı verilen konutlar, bu nedenle ortaya çıkmıştır. Bu anlayış ile gelişen yeni konut örüntüleri, günümüzde apartman olarak adlandırılan konut biçimlerine dönüşmüştür.

Günümüz toplumlarının barınma ihtiyacının büyük çoğunluğunu karşıladığı konut türü olan apartman, "birkaç katlı ve her katında bir veya birkaç daire bulunan yapı" anlamına gelirken; bu sözcük dilimize Fransızca "appartement" kelimesinden geçmiştir (Salbacak, 2019). Apartman sözcüğünün diğer tanımlamalarına bakıldığında "Ayrı yaşam birimleri olarak düzenlenmiş çok sayıda daireyi bulunduran, asansör ve isıtma sistemi gibi bazı konfor elemanlarının genellikle ortak kullanıldığı çok katlı yapı" olarak da tanımlanmaktadır (URL 1, 1993).

Apartmanların Geleneksel Türk Evi çatısı altında bir ya da iki katlı konutlarda yaşayan Türk insanının hayatına girişi, 18. yüzyılda Avrupa'da gerçekleşen Sanayi Devrimi'nin dünya toplumlarına etkileri sonrası biraz zaman almış; bu konutlar ancak 19. yüzyıl sonu ile 20. yüzyılın başında Türk konut kültürüne girmiştir. Çok katlı ve çok ailelik yaşam, yani apartman yaşamı; Türkiye'de 19.yüzyıl sonlarında başlamış, pek çok farklı biçime evrilerek çeşitlenmiştir (Görgülü, 2016). Yirminci yüzyılda Türkiye'nin konut külttüründeki değişimde en önemli rolü oynayan unsurlardan birisi, geleneksel konutların yerini apartmanların almasıdır (İnce Güney, 2009).

Yeni yapım teknik ve malzemelerinin çok katlı bina yapımına olanak tanıması, birçok ailenin barınmasına elverişli olması, modern ve konforlu yaşam şartlarına sahip olması, apartmanların en belirgin özellikleridir. Aynı zamanda apartmanlar, avlu ve bahçelere çok yer bırakmadan iç içe inşa edildikleri ve kent dokusunda bir sıkışıklık oluşturdukları için, fiziksel çevrede dönüşümler yaşanmasına paralel olarak, bu konutlarda sürdürülen yaşam biçimlerinin de değişmesine neden olmuşlardır (Öncel, 2014).

Bahçe, insanların zamanının büyük bir kısmını geçirdiği, çeşitli zevkleri tattığı yer anlamına gelmektedir (Gültekin, 1991). Yapıların dışında kalan, aynı zamanda yapının mülkiyeti altında olan alanlar kentte "bahçe" olarak adlandırılmıştır. Bu alanlar, yapılardan sonra kent içinde çok yer kaplayan, yapılarda oturan veya çalışan kişilerin kullandığı, günlük yaşamları ile bütünlük sağlayan mekanlardır. Çoğunlukla yeşille donatılan bu alanlar, doğaya olan özlemin giderildiği, doğa ile bütünleşmede önemli rol oynayan mekanlardır (Bakan ve Konuk, 1987).

İnsanların barınma ihtiyaçlarının karşılanması yanında sosyolojik yönden önemli ihtiyaçların karşılanmasına yardımcı olan konut bahçeleri, kentsel açık yeşil alan birimlerinden birisi olarak kabul edilmektedir (Kuş Şahin, 2008). Bu çalışma kapsamında, Isparta kent merkezindeki apartman bahçeleri estetik ve işlevsel açıdan incelenerek, mevcut durumlarının ortaya konulması ve bahçelerde kullanılan bitkisel materyallerin tespiti amaçlanmıştır.

\section{Materyal ve Metot}

\subsection{Materyal}

$\mathrm{Bu}$ araştırmada, Isparta kent merkezinde rasgele örnekleme yöntemi ile değişik mahallelerde belirlenmiş apartman bahçelerinde kullanılan ağaç, ağaçcık, çalı ve yer örtücü bitkiler incelenmiştir. Bunların dışında, çalışma kapsamında bahçelerde yer alan meyve ve sebzeler de tespit edilerek listelenmiştir. Ayrıca apartmanlarda ikamet eden ve değişik sosyo-kültürel özellikler taşıyan bireylerin, bahçe düzenlemesindeki eğilimlerinin belirlenmesi, bahçe bakımına verdikleri önemin tespiti, bahçelerinde kullandıkları bitkisel 
materyalleri hangi kriterlere veya özelliklerine göre seçtikleri, bu materyallerin ekimi, dikimi ve bakımı konularında yeterli bilgiye sahip olup olmadıkları araştırılmıştır.

$\mathrm{Bu}$ çalışmanın materyalini Isparta kent merkezinde, farklı mahallelerde bulunan apartman bahçeleri ile bu bahçelerin kullanıcıları oluşturmaktadır. Akdeniz Bölgesi'nin kuzeyinde Göller Bölgesi'nde yer alan Isparta ili, doğudan Konya İli’nin Beyşehir, Doğanhisar ve Akşehir ilçeleri; kuzeyden Afyonkarahisar İli'nin Çay, Şuhut, Dinar ve Dazkırı ilçeleri; batıdan Burdur İli’nin Merkez, Ağlasun ve Bucak ilçeleri; güneyden ise Antalya İli'nin Serik ve Manavgat ilçeleri ile çevrilmiştir (URL 2, 2020). https://ispartada.gen.tr/isparta-genel-bilgiler) (Şekil 1).

Akdeniz iklimi ile karasal iklim arasında geçiş bölgesinde yer alan Isparta ve çevresinde, her iki iklimin özellikleri de görülmektedir. Fakat, Akdeniz kıyılarında görülen sıcaklık ve yağış özellikleri ile karasal iklimin düşük sıcaklık ve düşük yağış özellikleri tam olarak gözlenemez (URL 3, 2004). Isparta kent merkezinde yılın en soğuk ayları genellikle Ocak-Şubat ayları, en sıcak aylar ise Temmuz ve Ağustos aylarıdır. Isparta, genel olarak kışları ılık ve yağışlı, yazları sıcak ve kurak bir iklime sahiptir (URL 4, 2020).

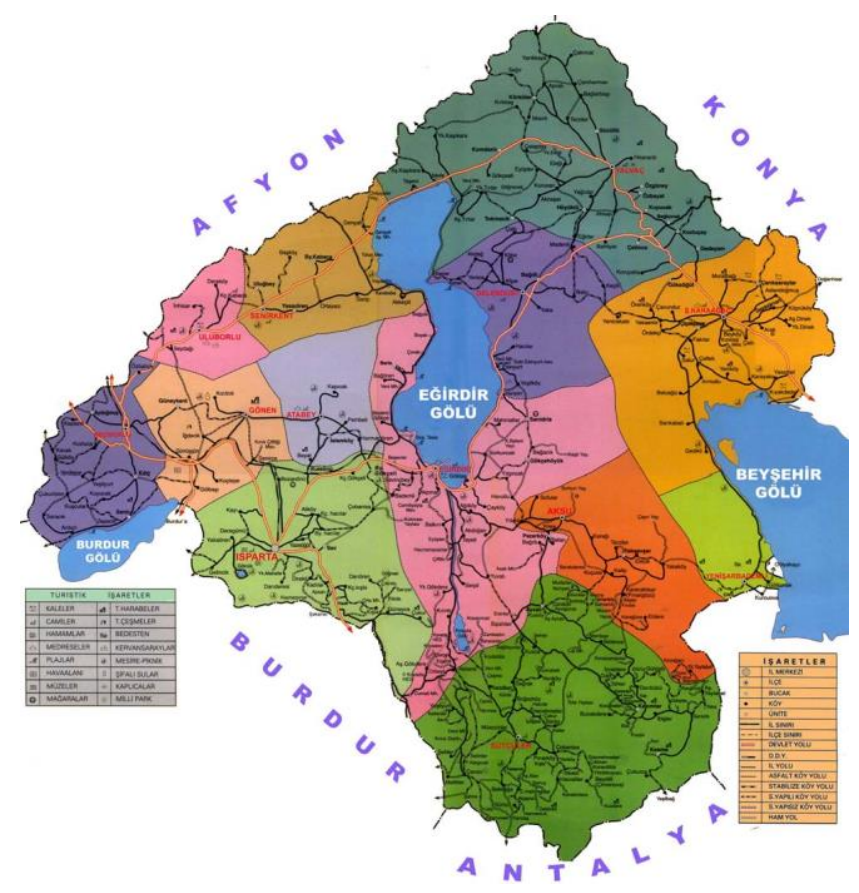

Şekil 1. Isparta il haritası ve çevresi (http://www.rehhber.com/resim/sehir/isparta/20-01.jpg)

Isparta kent merkezindeki apartmanlar bahçe yapıları ve büyüklükleri açısından:

- Bahçesiz,

- Küçük bahçeli ve

- Büyük bahçeli apartmanlar

olarak 3 grup altında toplanabilmektedir:

Çalışma kapsamında, Isparta kent merkezindeki apartmanlar incelenirken, bahçesiz olan apartmanlar inceleme kapsamına alınmamıştır.

\subsection{Metot}

Apartman bahçeleri için kullanılacak anket sorularının belirlenmesinde, açık uçlu soruların bulunmaması gerektiğine karar verilmiştir. Araştırmada hedeflenen sonuca ulaşabilmek için, bahçe ile en fazla ilgilenen veya bahçeye en fazla eğilimi olan konut sakini (çoğunlukla yönetici, apartman görevlisi veya bahçıvan vb) ile yüz yüze görüşülerek anket uygulaması yapılmıştır. İlk olarak Isparta kent merkezindeki anketlerin uygulanacağ 1 mahalleler seçilmiştir. Anket uygulanacak mahallelerin belirlenmesinin ardından, örnek popülasyonunun gerçek popülasyonu temsil etmesi için farklı tip olasılıklı, basit rastgele örnekleme metodu kullanılmıştır. Bu bağlamda, Isparta kent merkezindeki 32 mahallede, uygun örnekleme yöntemi ile apartman bahçeleri seçilmiştir. $\mathrm{Bu}$ kapsamda çalışma, 151 apartmanda ikamet eden 151 deneğin ankete katılmasıyla gerçekleştirilmiştir. Anket sonucunda elde edilen veriler ayrı ayrı değerlendirilmiştir. 
Bahçeli çok katlı apartmanların genel özellikleri ile buralarda ikamet edenlerin ortak kullanım alanı olan bahçelerin kullanım amaç ve şekillerinin, alandaki bitkisel materyallerin özelliklerinin, bahçe bakımı için sarf edilen zaman ve masraf bilgilerinin belirlenmesi amacıyla hedef kitleyi temsil edebilecek özellikteki mahallelerde bulunan bahçeli apartmanlar incelenmiş ve anket çalışmasının 32 mahallede uygulanmasına karar verilmiştir. Başlangıçta her mahalleden rastgele seçilecek 5 apartmanda yapılması planlanan anketler, yeterli deneğe ulaşılamaması ve diğer (deneklerin ankete katılmak istememesi, mahalle sınırları içinde yeterli sayıda apartman bulunmaması vb) bazı güçlüklerden dolayı Zafer mahallesinde 1, Dere mahallesinde 2, Vatan mahallesinde ise 3 adet olarak uygulanmıştır. Tablo 1'de Isparta kent merkezinde anket uygulanan mahalleler ve anket sayıları verilmiştir. Apartmanlarda yapılan anketler; apartman yöneticisi, apartman görevlisi (kapıcı), ev sahipleri gibi bahçeyle en çok ilgilenen kişilere uygulanmıştır. Kent merkezindeki 11 mahalle, çok az sayıda veya hiç apartman bulunmaması, apartmanların istenilen özellikte olmaması veya bunların az sayıda bulunması, apartmanda ikamet edenlerin ankete katılmak istememeleri, apartmanlarda bahçeyle ilgilenen kişilerin bulunmaması vb nedenlerle anket çalışması dışında tutulmuştur.

Anket uygulamaları, Mayıs-Eylül ayları arasında, havanın sıcak ve güneşli olduğu zamanlarda yapılmıştır. Anket uygulaması temsil açısından daha kapsamlı olması amacıyla, hafta içi ve hafta sonu sabah erken saatten güneş batımına kadar yapılmıştır. Yüz-yüze yapılan her bir anketin uygulanması yaklaşık 10-12 dakika sürmüştür.

Apartmanlara ait bahçeler; yerinde ayrıntılı olarak incelenmiş, alanda bulunan bitkiler tespit edilmiş, kullanım amaçları, yoğunlukları ile bitkisel tasarım ve alternatif alan kullanımı yönünden bazı değerlendirilmeler yapılmıştır. Ayrıca ziyaret edilen konut bahçeleri ve kullanılan bitkisel materyalin durumunu yansıtacak fotoğraflar çekilmiştir. Anket uygulanan kişilerin, soruları doğru anlayıp anlamadığı yüz yüze görüşmenin getirdiği avantajlardan dolayı kontrol edilmiştir. Anket sorularının bitiminde, bireylere kişisel önerisi, düşüncesi olup olmadığ 1 sorulmuş ve özgürce konuşması sağlanmıştır. Anketin son kısmında, bahçelerde kullanılan bitkisel materyallerin cins, tür ve familyasına ait ayrıntılı bilgilerle birlikte bitkinin, Türkçe ve Latince isimlerinin not edileceği çizelgeler de yer almıştır. Ayrıca alan ile ilgili gözlemler, alan kullanımı ve tür seçimindeki doğru ve yanlış olduğu düşünülen uygulamalar da not edilmiştir.

Isparta kent merkezindeki apartman bahçelerinin kullanım şekillerinin ve bahçelerdeki bitkisel materyallerin belirlenmesi aşamasında uygulanan anketler, SPSS 13.0 (Statistical Program for the Social Science) istatistik programının yardımıyla değerlendirilerek, tablolar halinde gösterilmiştir. Çalışmanın sonucunda da elde edilen veriler doğrultusunda öneriler getirilmiştir.

Tablo 1. Isparta kent merkezindeki apartman bahçeleri için yapılan anket sayılarının mahalle bazında dağılımı

\begin{tabular}{|c|l|c|c|l|c|}
\hline $\begin{array}{c}\text { Sıra } \\
\text { No }\end{array}$ & Anket Uygulanan Mahalle & $\begin{array}{c}\text { Anket Sayısı } \\
\text { (Adet) }\end{array}$ & $\begin{array}{c}\text { Sıra } \\
\text { No }\end{array}$ & Anket Uygulanan Mahalle & $\begin{array}{c}\text { Anket Sayısı } \\
\text { (Adet) }\end{array}$ \\
\hline 1 & Anadolu Mahallesi & 5 & 17 & İstiklal Mahallesi & 5 \\
\hline 2 & Bağlar Mahallesi & 5 & 18 & Karaağaç Mahallesi & 5 \\
\hline 3 & Bahçelievler Mahallesi & 5 & 19 & Keçeci Mahallesi & 5 \\
\hline 4 & Batkent Mahallesi & 5 & 20 & Kepeci Mahallesi & 5 \\
\hline 5 & Binbirevler Mahallesi & 5 & 21 & Kurtuluş Mahallesi & 5 \\
\hline 6 & Çelebiler Mahallesi & 5 & 22 & Modernevler Mahallesi & 5 \\
\hline 7 & Dere Mahallesi & 2 & 23 & Muzaffer Türkeş Mahallesi & 5 \\
\hline 8 & Doğanc1 Mahallesi & 5 & 24 & Pirimehmet Mahallesi & 5 \\
\hline 9 & Emre Mahallesi & 5 & 25 & Sermet Mahallesi & 5 \\
\hline 10 & Fatih Mahallesi & 5 & 26 & Sidre Mahallesi & 5 \\
\hline 11 & Gülcü Mahallesi & 5 & 27 & Sülübey Mahallesi & 5 \\
\hline 12 & Gülistan Mahallesi & 5 & 28 & Turan Mahallesi & 5 \\
\hline 13 & Hanifesultan Mahallesi & 5 & 29 & Vatan Mahallesi & 3 \\
\hline 14 & Hizırbey Mahallesi & 5 & 30 & Yedişehitler Mahallesi & 5 \\
\hline 15 & Hisar Mahallesi & 5 & 31 & Yenice Mahallesi & 5 \\
\hline 16 & İskender Mahallesi & 5 & 32 & Zafer Mahallesi & 1 \\
\hline
\end{tabular}

\section{Bulgular ve Tartışma}

Araştırmada elde edilen bulgular iki ana başlık altında sunulmuştur. Öncelikle apartman bahçelerindeki bitkisel materyaller yerinde tespit edilmiş ve gözlem sonucunda elde edilen bulgular sunulmuştur. Daha sonra ise anket sonuçları verilmiştir. 


\subsection{Apartman Bahçelerinin Fiziksel Özellikleri ve Gözlem Bulguları}

Yerinde gözlem ve anket uygulaması yapılan 151 apartman bahçesi genel görünümleri açısından incelendiğinde; bahçelerde rastgele, gelişigüzel bitkilendirmelerin yapıldığı, alanların küçük olduğu, bitki sayılarının fazla olduğu görülmektedir. Az sayıda olsa da bitkilerin planlı yerleştirildiği apartman bahçelerine rastlanılmıştır. Apartman sakinlerinin çevre düzenleme projesi hazırlatmadan bahçe düzenlemeleri yapmaları, bu durumun oluşmasını zaten açıklamaktadır. Ayrıca, apartmanların bahçelerinin kapladığı alanların küçük olması ve ikamet edenlerin bir kısmının aynı alanda, aynı zamanda bitki yetiştirmek istemesi, apartmanda görevli kişilerin kendi oturdukları kısımlarda özellikle sebze bahçesi şeklinde düzenleme eğilimleri, birçok apartman bahçesini karmaşık ve yoğun bitkilendirme yapılmış gibi göstermektedir. Daha az sayıda, projesi hazırlanmamış bazı apartman bahçelerinde de bitki yetiştirildiği, düzenlemelerin yapıldığı da gözlemlenmiştir. Tablo 2'de Isparta kent merkezindeki apartman bahçelerinin genel görünümleri itibari ile durumları verilmiştir.

Tablo 2. Apartman bahçelerinin genel görünümleri

\begin{tabular}{ll}
\hline Alanın Genel Görünüşü & Rastlanma Sayısı (Adet) \\
\hline Bitkiler rastgele yerleştirilmiş & 81 \\
Bahçe alanı dar, bitki sayısı fazla & 53 \\
Bahçe tamamen bitkilendirilmiş & 25 \\
Bahçe alanı geniş, bitki sayısı az & 21 \\
Bitkiler planlı bir şekilde yerleştirilmiş & 14 \\
\hline
\end{tabular}

Yapılan araştırma sonucunda, apartman bahçelerinde yetiştirilen bitkilerden herhangi bir gelir elde edilmediği anlaşılmıştır. Zira, ortak kullanım alanında yetiştirilen bitkilerin tek bir kişi veya kişiler için fayda sağlaması mümkün değildir. Apartman bahçelerinde; estetik amaçla yetiştirilen çiçekler, çalılar, ağaççıklar ve ağaçların yanı sıra meyve ve sebze türlerine de rastlanılmıştır. Tablo 3'te apartman bahçelerinde en fazla görülen bitkisel materyaller ve rastlanma sıklıkları verilmiştir.

Bahçe alanı geniş olan apartmanların bahçelerinde geniş yapraklı ağaçlarla birlikte iğne yapraklı ağaçların birlikte kullanılmasıyla oluşan gruplar, estetik görünümler sunmaktadır. Ancak alanı dar olan bahçelerde, geniş taç yapan türlerin kullanımı sıkışıklık yaratmakta, bu da hoş olmayan görüntüler ortaya çıkarmaktadır. Geniş yapraklı ağaçlardan; Platanus orientalis (doğu çınarı), Gleditsia triacanthos (gladiçya), Acer pseudoplatanus (yalancı çınar yapraklı akçaağaç), Acer platanoides (çınar yapraklı akçaağaç), Robinia pseudacacia (yalancı akasya), Fraxinus excelsior L. (adi dişbudak), Ulmus campestris (sahra karaağacı) özellikle bahçe alanı dar olan apartman bahçeleri için uygun değildir. Isparta kent merkezindeki apartman bahçelerinden bir tanesinde doğu çınarı ve üç tanesinde de yalancı akasya yer almaktadır. Fazla geniş alana sahip olmayan apartman bahçeleri için uygun olan türler ise, orta büyüklükteki ağaç ve ağaçcık türleridir. Bunlara da örnek olarak Eleagnus angustifolia (iğde), Acer campestre (sahra akçaağacı), Liquidamber orientalis (sı̆̆la ağacı), Crataegus monogyna (alıç), Sorbus aucuparia (üvez), Aesculus carnea (pembe çiçekli atkestanesi) verilebilir. Isparta kent merkezindeki apartman bahçelerinde özellikle iğne yapraklı ağaçlar, geniş yapraklılara oranla daha fazla sayıda yer almaktadır. İğne yapraklı ağaçlar, geniş bir yapıya sahip oldukları için alanları dar olan apartman bahçelerinde fazla kullanılmamalıdır. Çalılar da kendi içlerinde grup oluşturacak şekilde kullanılabilmektedirler. Apartman bahçelerinde Euonymus japonica (taflan), Euonymus japonica "aurea" (sarı alacalı taflan), Spiraea vanhouttei (keçi sakalı), Cotoneaster horizontalis (yayılıcı dağ muşmulası), Cornus alba (süs kızılcı̆ğ), Philadelphus coronarius (filbahri), Mahonia aquifolium (mahonya) vb duvar kenarlarında, çim alanlarda, yol kenarlarında gruplar halinde kullanıma uygun olan çalılardır. Apartman bahçelerinde kuşatmak, çevrelemek için kullanılan örtü çalılarının en önemli fonksiyonları, gürültü ve tozu önlemek ve mahremiyeti sağlamaktır. Bu amaçlarla kullanılacak olan örtü çalılarına örnek olarak; Spiraea vanhouttei (keçi sakalı), Ribes aureum (Frenk üzümü), Pyracantha coccinea (ateş dikeni), Symphoricarpos albus (beyaz inci çalısı), Cornus alba (süs kızılcığı), Syringa vulgaris (leylak), Philadelphus coronarius (filbahri) vb çalılar verilebilir. Isparta kent merkezindeki konut bahçelerinde bu çalılara sıkça rastlanmaktadır. Isparta kent merkezindeki apartman bahçelerinde rastlanılan ibreli ağaçlardan Picea pungens 'Glauca' (mavi ladin) çim alanlar üzerinde, soliter olarak kullanıma uygundurlar. Apartman bahçelerinden bir tanesinde mavi ladin bulunmaktadır. Geniş yapraklı ağaçlardan Salix alba (ak söğüt) soliter olarak kullanılabilen bir tür olmasına rağmen konut bahçelerinde kullanılmamalı, daha çok su kenarlarında kullanılmalıdır. Ancak ak söğüt apartman bahçelerinden dördünde yer almaktadır. Isparta kent merkezindeki apartmanların bahçelerinde, en fazla kullanılan bitki türlerinin meyveler olduğu görülmektedir. Bahçelerdeki meyvelerin kullanım yoğunluğuna bakıldığında ise, 151 bahçenin 109 tanesinde asma yetiştirilmekte, bunu 85 bahçe ile kayısı, 72 bahçe ile erik, 67 bahçe ile kiraz ve 58 bahçe ile ayva izlemektedir. Portakal, Sarı kiraz, fistık, zerdali ve limon ise sadece birer bahçede yer almaktadır. Bahçelerde bulunan sebzeler ise meyvelere oranla daha az sayıdadır. Bahçelerdeki sebze kullanımı incelendiğinde ise; 66 bahçede soğan, 58 bahçede nane, 35 bahçede domates, 24 bahçede biber ve 21 bahçede 
de marul yer almaktadır. Dere otu, pırasa, roka, kabak, kara lahana, bakla, kuzu kulağı ve kekik ise sadece birer bahçede mevcuttur (Tablo 3).

Tablo 3. Isparta kent merkezindeki apartman bahçelerinde en fazla bulunan bitkisel materyaller

\begin{tabular}{|c|c|c|c|c|c|}
\hline \multicolumn{3}{|c|}{ MEYVELER } & \multicolumn{3}{|c|}{ SEBZELER } \\
\hline Latince Adı & Türkçe Adı & Adet & Latince Adı & Türkçe Adı & Adet \\
\hline Vitis vinifera $\mathrm{L}$. & Asma & 109 & Allium cepa $\mathrm{L}$. & Soğan & 66 \\
\hline Prunus armeniaca $\mathrm{L}$. & Kayıs1 & 85 & Mentha piperita $\mathrm{L}$. & Nane & 58 \\
\hline Prunus domestica $\mathrm{L}$. & Erik & 72 & Lycopersicon esculentum L. & Domates & 35 \\
\hline Prunus avium $\mathrm{L}$. & Kiraz & 67 & Capsicum annum $\mathrm{L}$. & Biber & 24 \\
\hline $\begin{array}{ll}\text { Cydonia } & \text { vulgaris } \\
\text { Pers. } & \\
\end{array}$ & Ayva & 58 & $\begin{array}{l}\text { Lactuca sativa var. } \\
\text { longifolia } \mathrm{L} .\end{array}$ & Marul & 21 \\
\hline Juglans regia $\mathrm{L}$. & Ceviz & 49 & Petroselinum hortense & Maydanoz & 20 \\
\hline Prunus cerasus L. & Vişne & 44 & Helianthus tuberosus L. & Yerelmas1 & 11 \\
\hline Prunus persica L. & Şeftali & 39 & Lepidium sativum $\mathrm{L}$. & Tere otu & 8 \\
\hline Punica granatum L. & Nar & 29 & Urtica dioica $\mathrm{L}$. & Isırgan otu & 8 \\
\hline Morus alba $\mathrm{L}$. & Beyaz dut & 25 & Allium sativum $\mathrm{L}$. & Sarımsak & 7 \\
\hline Prunus amygdalus L. & Badem & 25 & Spinacia oleracea $\mathrm{L}$. & Ispanak & 6 \\
\hline Pyrus communis $\mathrm{L}$. & Armut & 24 & Solanum melongena $\mathrm{L}$. & Patlican & 5 \\
\hline Malus communis L.. & Elma & 20 & Phaseolus vulgaris $\mathrm{L}$. & Fasulye & 5 \\
\hline \multicolumn{3}{|c|}{ GENIŞ YAPRAKLI AĞAÇLAR } & \multicolumn{3}{|c|}{ İĞNE YAPRAKLI AĞAÇLAR } \\
\hline Latince Adı & Türkçe Adı & Adet & Latince Adı & Türkçe Adı & Adet \\
\hline Tilia argentea Desf. & Gümüşi ihlamur & 17 & Cedrus libani A. Rich. & Toros sediri & 33 \\
\hline Populus alba $\mathrm{L}$. & Akkavak & 9 & Pinus nigra $\mathrm{L}$. & Kara çam & 30 \\
\hline Ailanthus altissima $\mathrm{L}$ & Cennet ağacı & 6 & Biota orientalis (L.) Endl. & Doğu mazısı & 29 \\
\hline Salix babylonica $\mathrm{L}$. & Salkım söğ̈̈t & 4 & Cupressus sempervirens L. & Mezarlık servisi & 18 \\
\hline Robinia pseudacacia L. & Yalancı akasya & 3 & Juniperus sabina $\mathrm{L}$. & Sabin ardic1 & 18 \\
\hline Acer negundo L. & $\begin{array}{c}\text { Dişbudak yapraklı } \\
\text { akçaağaç }\end{array}$ & 2 & Picea abies L. & Avrupa ladini & 13 \\
\hline Laurus nobilis L. & Akdeniz defnesi & 2 & $\begin{array}{ll}\text { Cupressus } & \text { macrocarpa } \\
\text { 'Gold Crest' } & \\
\end{array}$ & Limoni servi & 9 \\
\hline Fraxinus excelsior $\mathrm{L}$. & Adi dişbudak & 1 & Abies cilicica Carr. & Toros göknarı & 4 \\
\hline Platanus orientalis $\mathrm{L}$. & Doğu çınarı & 1 & Taxus baccata $\mathrm{L}$. & Adi porsuk & 2 \\
\hline Sophora japonica $\mathrm{L}$. & Sofora & 1 & Picea pungens 'Glauca' & Mavi ladin & 1 \\
\hline \multicolumn{3}{|c|}{ AĞAÇCIKLAR VE ÇALILAR } & \multicolumn{3}{|c|}{ TEK, İKI VE ÇOK YILLIK ÇiÇEKLER } \\
\hline Latince Adı & Türkçe Adı & Adet & Latince Adı & Türkçe Adı & Adet \\
\hline Rosa spp. & Gül & 115 & Lilium canadense $\mathrm{L}$. & Zambak & 70 \\
\hline Lonicera nitida $\mathrm{L}$. & Hanımeli & 57 & $\begin{array}{l}\text { Chrysanthemum } \\
\text { coronarium } \mathrm{L} .\end{array}$ & $\begin{array}{l}\text { Kasımpat1, } \\
\text { Krizantem } \\
\end{array}$ & 43 \\
\hline Syringa vulgaris L. & Adi leylak & 21 & Antirrhinum majus $\mathrm{L}$. & Aslanağzı & 36 \\
\hline $\begin{array}{l}\text { Euonymus japonica } \\
\text { L. }\end{array}$ & Taflan & 18 & Viola tricolor maxima & $\begin{array}{l}\text { Hercai } \\
\text { menekşe }\end{array}$ & 28 \\
\hline $\begin{array}{l}\text { Euonymus japonica } \\
\text { "Aureus" }\end{array}$ & $\begin{array}{l}\text { Sar1 alacal1 } \\
\text { taflan }\end{array}$ & 11 & Althaea rosea (L.) Cav. & $\begin{array}{l}\text { Gülhatmi, } \\
\text { Hatmi }\end{array}$ & 28 \\
\hline $\begin{array}{l}\text { Pyracantha coccinea } \\
\text { Roem. }\end{array}$ & Ateş dikeni & 11 & Dianthus barbatus L. & Hüsnüyusuf & 23 \\
\hline Buxus sempervirens L. & Adi şimşir & 10 & Tagetes erecta $\mathrm{L}$. & Kadife çiçeği & 22 \\
\hline Nerium oleander L. & Zakkum & 9 & Anthemis maritima $\mathrm{L}$. & $\begin{array}{l}\text { Papatya } \\
\text { (beyaz) }\end{array}$ & 22 \\
\hline Viburnum oplulus L. & Adi kartopu & 9 & Cheiranthus cheiri L. & Şebboy & 16 \\
\hline $\begin{array}{l}\text { Jasminum fruticans } \\
\text { L. }\end{array}$ & $\begin{array}{l}\text { Sarı çiçekli } \\
\text { yasemin }\end{array}$ & 9 & Rosmarinus officinalis $\mathrm{L}$. & $\begin{array}{l}\text { Biberiye, } \\
\text { Rosmarin }\end{array}$ & 15 \\
\hline Ligustrum vulgare $\mathrm{L}$. & Adi kurtbağrı & 4 & Calendula officinalis & Portakal nergisi & 14 \\
\hline $\begin{array}{l}\text { Hydrangea } \\
\text { arborescens } \mathrm{L} .\end{array}$ & Ortanca & 3 & Hyacinthus orientalis $\mathrm{L}$. & Sümbül & 12 \\
\hline \multicolumn{6}{|c|}{$\begin{array}{l}\text { SARILICI VE TIRMANICI BITTKILER } \\
\end{array}$} \\
\hline Latince Adı & Türkçe Adı & Adet & Latince Adı & Türkçe Adı & Adet \\
\hline Hedera helix $\mathrm{L}$. & Kaya sarmaşı̆̆ 1 & 26 & Wisteria sinensis (Sims.) DC. & Mor salkım & 13 \\
\hline $\begin{array}{l}\text { Parthenocissus } \\
\text { quinquefolia } \mathrm{L} .\end{array}$ & $\begin{array}{l}\text { Amerikan } \\
\text { sarmaşı̆̆ } 1\end{array}$ & 19 & $\begin{array}{lll}\text { Campsis } & \text { radicans } & (\mathrm{L} .) \\
\text { Seem. } & & \\
\end{array}$ & $\begin{array}{l}\text { Acem borusu, } \\
\text { Borazan }\end{array}$ & 5 \\
\hline Rosa wichuraiana & Sarılıcı gül & 18 & Lonicera caprifolium $\mathrm{L}$. & Hanımeli & 2 \\
\hline
\end{tabular}


En az miktarda kullanılan bitki türü ise süs bitkisi olarak kullanılan geniş yapraklı ağaçlardır. Bunun en büyük nedenlerinden birisi, bahçe alanlarının dar olmasıdır. Apartmanların bahçelerinde süs bitkisi olarak kullanılmış olan geniş yapraklı ağaçlara bakıldığında ise; 17 bahçe ile ıhlamur türü en yoğun olarak kullanılmıştır. Bunu, 9 bahçe ile akkavak, 6 bahçe ile cennet ağacı, 4 bahçe ile salkım söğüt ve 3 bahçe ile yalancı akasya takip etmektedir. Adi dişbudak, doğu çınarı, sofora, duman ağacı, katalpa ve gümüşi akasya ise sadece birer apartman bahçesinde bulunmaktadır. İğne yapraklı ağaçlar geniş yapraklılara oranla daha fazla sayıda kullanılmıştır. İğne yapraklı ağaçlarda ise önceliği 33 bahçe ile Toros sediri ve 30 bahçe ile kara çam almaktadır. Daha sonra ise; 29 bahçe ile doğu mazısı, 18 bahçe ile adi servi ve yine 18 bahçe ile sabin ardıcı izlemektedir. Mavi ladin ise sadece 1 apartman bahçesinde bulunmaktadır. Ağaçcık ve çalılara bakıldığında; 115 bahçe ile gül, 57 bahçe ile hanımeli ilk sıraları alırken, 21 bahçe ile leylak, 18 bahçe ile taflan ve 11 bahçe ile sarı alacalı taflan bunları takip etmektedir. Beyaz inci çalısı, ağaç hatmi ve süs kızılcığı ise birer adet ile en az sayıda kullanılan bitkilerdir. Sarmaşıklar, sarılıcı ve tırmanıcı bitkilerde ise; 26 bahçede kaya sarmaşı̆̆ı, 19 bahçede Amerikan sarmaşığı, 18 bahçede sarılıcı gül ve 13 bahçede mor salkım kullanılmıştır. En az ise 5 bahçede acem borusu ve 2 bahçede hanımeli mevcuttur. Çiçeklere bakıldığında ise; 70 bahçede zambak, 43 bahçede kasımpatı, 36 bahçede aslanağzı, 28 bahçede hercai menekşe ve yine 28 bahçede gülhatmi mevcuttur. Gazanya, çin karanfili, yıldız çiçeği, süs lahanası, mine çiçeği, hanım düğmesi ve kaktüs ise sadece birer apartmanın bahçesinde yer almaktadır. Bitkisel materyallerin genel görünüşü açısından 59 bahçenin bakımlı, yine 59 bahçenin bakımsız olduğu, 25 bahçede de bitkisel materyallerin anormal derecede büyümüş olduğu görülmüştür. Şekil 2'de, Isparta kent merkezinde incelenmiş bahçelerin genel görünümleri ile birlikte, rastlanılan bitkisel materyaller yer almaktadir.
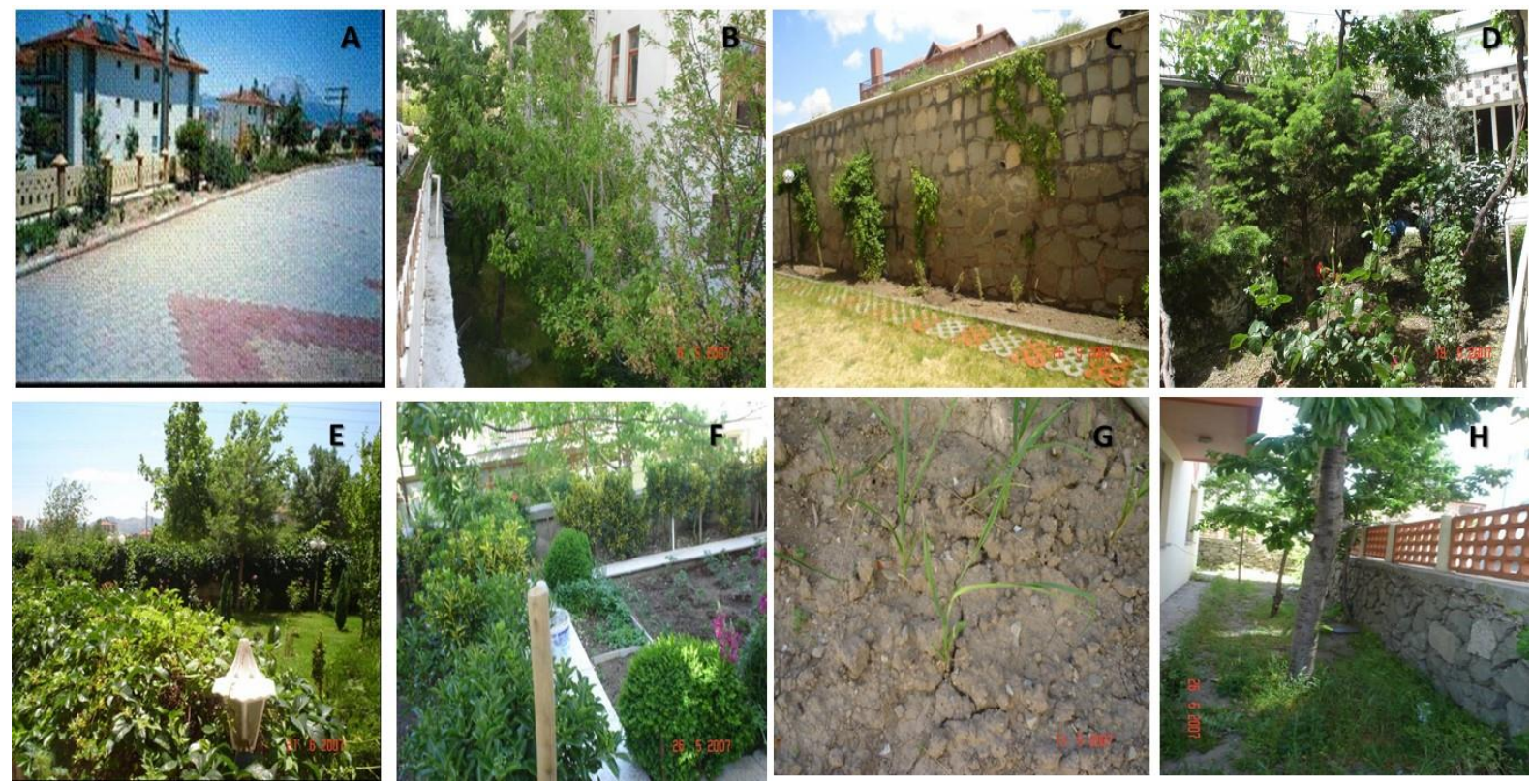

Şekil 2. Isparta kent merkezindeki bazı apartman bahçelerinin genel görünüşleri (A: Bahçe alanı geniş, bitki sayısı az; B: Bahçe alanı dar, bitki sayısı fazla; C: Planlı yerleştirilmiş bitkiler; D: Tamamen bitkilendirilmiş; E-F: Bakımlı bitkisel materyaller; G: Bakımsız bitkisel materyal; H: Gelişimi engellenmiş bitkisel materyaller)

\subsubsection{Isparta kent merkezindeki apartman bahçelerinin bitkisel tasarım açısından değerlendirmesi}

Kentlerde imar yönetmeliklerinde verilen bahçe büyüklüklerine fazla uyulmadığı ya da bahçe alanı içinde depo, garaj, otopark, kömürlük, kümes vb kullanım alanlarının bulunduğu gözlenmektedir. 3194 sayılı imar kanununda yer alan bahçe mesafeleri $5 \mathrm{~m}$ olmasına rağmen (ön ve yol kenarına rastlayan yan bahçe mesafeleri), bazı konutlarda bu mesafenin göz ardı edildiği görülmektedir.

Kent merkezindeki bazı apartman bahçeleri, büyük alanlara sahiptirler. Bu bahçelerde; fonksiyon, bitkisel materyal çeşitliliği ve içerik bakımından farklılıklar görülmektedir. Bu tür bahçelerin düzenlenmesinde özen ve bakım gösterilmekte, bu bahçelerin estetik özelliklerinin süreklilikleri sağlanmaktadır. Bahçelerde ölçü, biçim, doku ve renk açısından bitkisel materyaller ile kompozisyonlar oluşturulmuş, böylece bahçelere hareket kazandırılmış, aynı zamanda bahçeler sakin, huzur verici mekanlar haline dönüştürülmüş haldedir. 
Apartman bahçelerinde, mekâna farklılık kazandırmak amacıyla kaba ve hafif dokulu bitkiler, kontrast yaratacak biçimde birlikte kullanılmışlardır. Bitkiler, gövde ve dal renkleri (Cornus mas L., Berberis thunbergii var. atropurpurea), sonbahar renkleri (Mahonia aquifolium Nutt.), çiçek renkleri (Lagerstroemia indica L., Cercis siliquastrum L. vb), gri (gümüşi) renkleri (Olea europea L., Eleagnus angustifolia L. vb) özellikleri için seçilmiş olduğu düşünülmektedir.

Apartman bahçelerinde, bahçe içinde mekanları ayırmak için yapısal elemanların yerine bitkisel materyaller de kullanılmıştır. Bu amaçla çit bitkisi olarak kullanılan türler tercih edilmiştir.

Soliter bitki, o türü temsil eden örnek bitkidir. Kırmızı, sarı, mavi, gümüşi renkli bitkiler, güzel çiçekli bitkileri, salkım, sütun, küre, yatık, piramit vb. formlu ağaç, ağaçcık ve çalılar tek başına kullanıldıkları zaman daha etkili olurlar. Çim alanda tek başına veya bir çalı kitlesi içinde ilgi çekmek amacıyla kullanılan obje olabilir. Soliter bitkinin yer aldığı kısım Vinca minor, Hedera helix ya da çim gibi yer örtücülerle de belirlenebilir. Soliter bitkiler, onunla rekabet edecek bir başka bitkinin yakınında olmamalıdır. Teras ve merdiven kenarlarında, duvar önlerinde kullanılmaları uygundur.

Apartman bahçelerindeki geniş ve yüksek tepe çapı yapan ağaçlar, mekân yaratırlar. Bu tür ağaçlar; gölge, barınak sağlar, duygusal ve fiziksel güven hissi verirler. Bir nirengi noktası veya dikey bir sembol olarak kullanılabilirler. Bu özelliğinden dolayı peyzaj uygulamalarında herhangi bir yerin tanınmasına hizmet ederler. İğne yapraklı ağaçlar da apartman bahçelerinde sık kullanılmaktadırlar. Bahçelerdeki bitkisel tasarımlarda, ağaçların mekân yaratma ve kuşatma gibi estetik ve mimari fonksiyonları vardır. Kullanılan ağaçlar, gölge alan oluşturma görevini yerine getirerek ve etrafı çevreleyerek mekân oluşturabilir. Gölge için kullanılan ağaçların ya da geniş çim alanlardaki ağaçların altları boş bırakılır. Kuşatma elemanı olarak kullanılan ağaçlar kademeli olarak yükselmelidir. En ön sırada çiçekler sonra çalılar, ağaçcıklar ve en son sırada ağaçlar kullanılırlar. Tam kuşatmada dışarısı görünmez. Yarım kuşatmada ise ağaçların arasından görünüm ve geçiş sağlanır.

Bahçelere renk, hareket ve koku veren bitkisel materyaller olan çiçekler, tek çeşit halinde ya da karışık gruplar halinde kullanılmaktadır. Renk zenginliğiyle hem göze hem de ruha hitap ederler. Bahçe girişlerinde, duvar önlerinde, ön yan veya arka bahçelerde parter veya yastıklarda kullanılan çiçekler renkleriyle bahçelerde hareketlilik yaratmaktadırlar (Şekil 3).

Bazı apartmanların bahçelerinin bir tarafı muntazam bir şekilde düzenlenmişken (özellikle ön bahçe), diğer tarafı (özellikle arka bahçe) terk edilmişliğe bırakılmış ya da gelişigüzel bir bitkilendirme yapılmış, özel bir düzenleme yapılmamış olduğu, hatta depo olarak kullanıldığı görülmektedir. Ön bahçelerde, estetik ağırlıklı bitkiler, özellikle güzel çiçekli çalılar tercih edilmiştir. Yan ve arka bahçeler ise daha çok fayda bahçesi olarak ayrılmış olup genellikle meyvesinden yararlanılan ağaçların dikildiği ve ağaç altlarında ihtiyaca göre çeşitli sebzelerin yetiştirildiği belirlenmiştir. Bunun yanı sıra arka bahçelerde süs bitkilerine de rastlamak mümkündür (Şekil 3).

Bitkisel tasarımda, kent ölçeğinde geçmişte var olup günümüze çok az kalabilen, bölgenin iklim şartlarına uygun bitki türleri belirlenerek, günümüz mekânlarında da yeniden kullanılabilir hale getirilebilir. Bunun sonucunda da kullanılan bitkilerde önceliği geçmişten günümüze kadar Isparta bahçelerinde yetiştirilmiş olan türler almaktadır. Bununla birlikte anket yapılan apartman bahçelerinde Isparta gülü olarak adlandırılan bitki sadece 2 bahçede yetiştirilmekte olup, Hisar mahallesindeki apartman bahçesindeki bitki üzerine aşı yapılmıştır.

Apartmanların çoğunda peyzaj projesi çizdirilmediği için elde edilen her bitki dikilmiş, bu da bahçede karmaşaya neden olmuştur. Konutların geneline bakıldığında, çoğunda bitkilerin rastgele dikildiği, belirli bir plan dahilinde gerçekleştirilmediği görülmektedir. Çoğunda bitkilerin birbiriyle karışacak şekilde dikildiği; sebzelerin, meyve ağaçlarının ve süs bitkilerinin birbirine karışmış halde olduğu görülmektedir. 

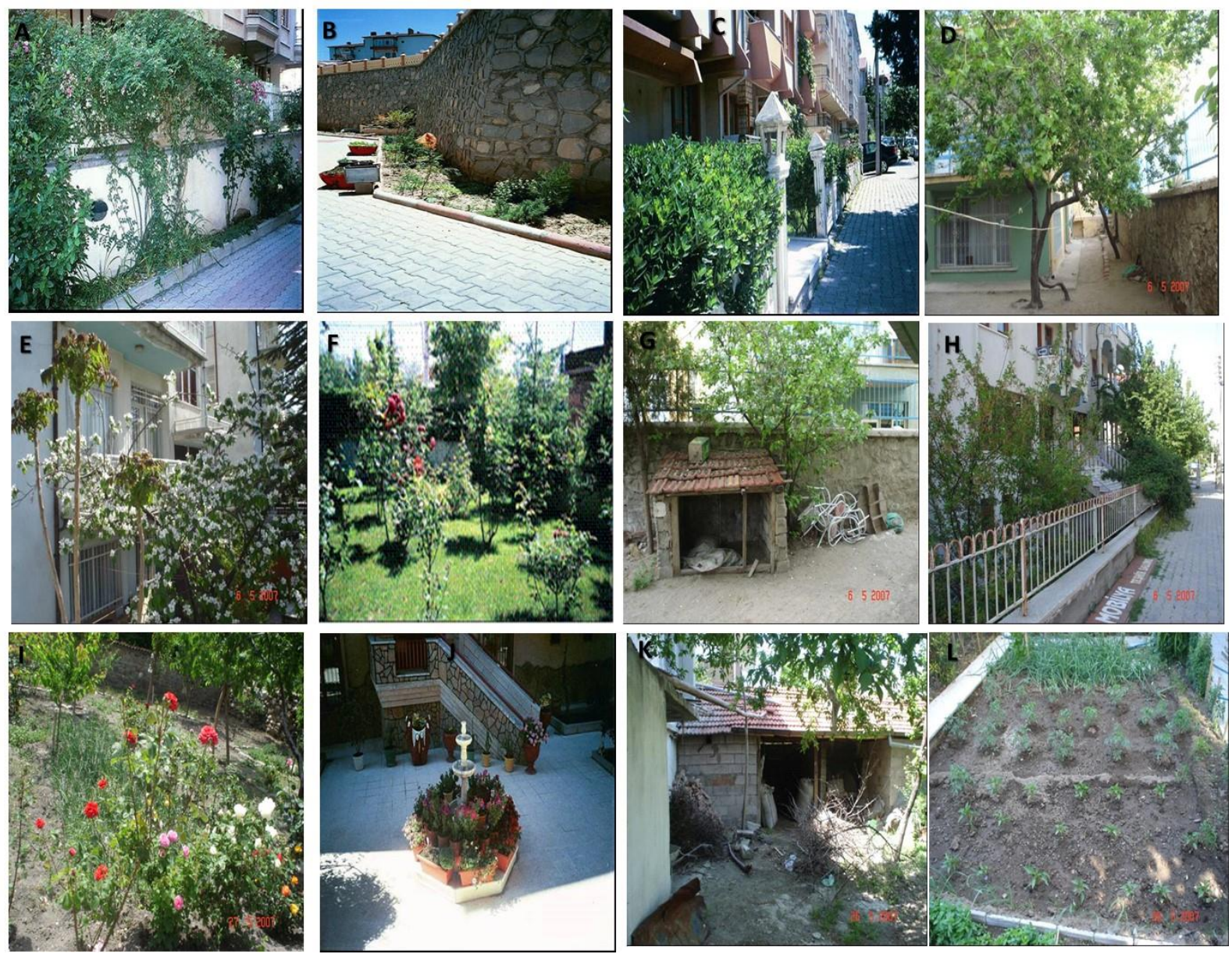

Şekil 3. Apartman bahçelerinin genel görünümleri (A: Bitkilerle sardırılmış çevreleme elemanı; B: Soğuk görüntü oluşturan çevreleme elemanı; C: Çit bitkisi olarak çalı kullanımı; D: Bahçede gölge etkisi için ağaç kullanımı; E: Yoğun bitkilendirilmiş bahçe; F: Bakımlı bir bahçe; G: Bahçede yer alan kümes; H: Dar alanda bitkilendirilmiş ön bahçe; I: Bahçedeki süs bitkileri; J: Arka bahçede süs havuzu içine yerleştirilmiş çiçekler; K: Özenilmemiş arka bahçe; L: Sebze bahçesi olarak düzenlenmiş arka bahçe).

Isparta kent merkezindeki apartmanların bahçelerinde rastlanılan ve özellikle Antalya'dan apartman sakinlerinin getirdikleri Actinidia chinensis (kivi), Citrus limonum (limon), Citrus sinensis (portakal), Washingtonia filifera (palmiye), Persea americana (avakado) vb. bitkiler, sıcak iklim bölgesinden geldiği için dış mekânda Isparta ilinin kışlarının sert geçmesi nedeniyle dayanamamakta, zaman zaman ölmektedir. Bu da halkın bitkiler konusunda fazla bilinçli, bilgili olmadığını göstermektedir.

Apartman bahçelerinde çalılara daha fazla yer verilmiştir. Bölümleme, ayırma, kapatıcı etki yaratma için estetik şekilde yapılan düzenlemeler olan çalı kitlesi uygulamalarına, araştırma yapılan apartman bahçelerinde rastlanmıştır.

\subsection{Anket Bulguları}

Anketlerin gerçekleştirildiği 151 apartmanın yapıldığı yıllar itibariyle durumu irdelendiğinde; apartmanların \%13'ünün hangi y1l yapıldığı konusunda kesin bilgi elde edilememiştir. Anket yapılan apartmanların bahçeleriyle en fazla ilgilenen kişilerin çoğunlukla orada ikamet eden ev sahipleri (\%37) olduğu anlaşılmıştır. İkinci sırada gelen kiracılar $(\% 35)$ daha çok ev sahiplerinin ikamet etmediği apartmanlarda bahçeyle ilgilenmektedirler. Daha az oranda olmak üzere diğer apartman sakinleri (\%8), apartman yöneticileri, görevli kapıcı / kalorifercilerin de (\%6) bahçeyle ilgilenenler arasında olduğu gözlenmiştir. Anket yapılan apartman bahçelerinin yaklaşık \%11'inde bahçe ile hiç kimsenin ilgilenmediği tespit edilmiştir. \%3'ünde ise konu ile ilgili bilgi elde edilememiştir. Isparta kent merkezindeki apartman bahçelerinin bakımı/düzenlenmesi ile ilgili elde edilen bilgiler Tablo 4'te verilmiştir. Buna göre apartman bahçelerinin çok büyük kısmında (\%90) herhangi bir çevre düzenleme projesi hazırlanmadığı anlaşılmıştır. Apartmanlarda toplu kullanıma açık düzenlenmelerle en çok ilgilenenlerin, ev sahipleri (\%40) ve apartman sakinleri (\%42) olduğu tespit edilmiştir. 
Tablo 4. Isparta kent merkezindeki apartman bahçelerinin bakım/masraf bilgileri

\begin{tabular}{ccc}
\hline Değişkenler & Verilen Cevaplar & Oranı (\%) \\
\hline Çevre Düzenleme Projesi Çizdirilme Durumu & Evet & 1 \\
& Hayır & 90 \\
Çevre Düzenlemesi Yapan Kişi & Bilinmiyor / Bilgi alınamadı & 9 \\
& Apartman görevlisi (Kapıcı) & 3 \\
& Kalorifer yakan kişi & 1 \\
& Yönetici & 7 \\
& Apartman sakinleri & 42 \\
Bahçede Düzenli Bakım Yapılma Durumu & Bilinmiyor / Bilgi alınamadı & 7 \\
& Ev sahibi & 40 \\
& Evet & 61 \\
Bahçe İçin Harcama Yapılma Durumu & Hayır & 36 \\
& Bilinmiyor / Bilgi alınamadı & 3 \\
& Evet & 42 \\
& Hayır & 55 \\
\hline
\end{tabular}

Apartman bahçelerinin büyük bir kısmında (\%61) düzenli olarak bakım yapılırken, \%36'sında ise bakım yapılmadığı anlaşılmış, \%3'ünden ise bu konuda bilgi alınamamıştır. Düzenli bakım yapılmayan apartman bahçelerinde bunun sebepleri araştırılmıştır. Buna göre; para ve zaman yetersizliği, düzenli bakım yapılmamasında başlıca nedenler arasındadır. Apartman bahçelerinin yaklaşık \%42'sinde bakım için belli bir miktar harcama yapıldığı, \%55'inde ise bu konuda herhangi bir harcama yapılmadığı belirlenmiştir. Ankete katılan 151 kişiye bahçenin kullanım amacı ve şeklini belirlemek amacıyla bahçe alanı, bahçeyi en çok kullanan kişiler, kullanım amacı ve bahçede beslenen hayvanlara ilişkin sorular yöneltilmiştir. Apartman bahçelerinin kapladığı alanlara ait bilgiler Tablo 5'te verilmiştir. Buna göre bahçelerin alan bakımından çok değişik büyüklüklerde olduğu anlaşılmıştır.

Tablo 5. Apartman bahçelerinin alan büyüklükleri

\begin{tabular}{|c|c|}
\hline Konutların Bahce Alanları & Rastlanma Sayısı (Adet) \\
\hline $0-50 \mathrm{~m}^{2}$ & 8 \\
\hline $51-100 \mathrm{~m}^{2}$ & 26 \\
\hline $101-150 \mathrm{~m}^{2}$ & 39 \\
\hline $151-200 \mathrm{~m}^{2}$ & 30 \\
\hline $201-300 \mathrm{~m}^{2}$ & 23 \\
\hline$>330 \mathrm{~m}^{2}$ & 25 \\
\hline
\end{tabular}

Bahçeleri, apartman sakinlerinden daha çok kadınların ve çocukların kullandığı anlaşılmıştır. Yaşlılar ve erkekler bahçeyi daha az kullanmaktadırlar. Bahçeyi en az kullananlar ise gençlerdir. Bahçesi hiç kimse tarafından kullanılmayan apartmanların oranı da oldukça yüksektir. Tablo 6'da apartman bahçelerini en fazla kullananlar ve rastlanma sayıları verilmiştir. Bahçenin genel olarak kullanım amaçları Tablo 7'de verilmiştir. Buna göre apartman bahçeleri en çok; oturma, oyun oynama ve dinlenme amaçlı kullanılmaktadır. Ayrıca apartmanlarda oturan kişilerin bahçelerini otopark olarak kullanımları da söz konusudur. Bu da zaten yetersiz olan bahçe alanını daha da azaltmaktadır. Bunun yanı sıra eskiden kullanılmış olan ancak günümüzde kullanılmayan kümes, kömürlük vb yapısal öğelerin bahçede yer alması da bahçe alanını daraltmaktadır. Bahçesi hiçbir amaçla kullanılmayan apartman bahçeleri de mevcuttur.

Tablo 6. Isparta kent merkezindeki apartman bahçelerini en fazla kullananlar

\begin{tabular}{ll}
\hline Bahçeyi En Fazla Kullananlar & Rastlanma Sayısı (Adet) \\
\hline Kadınlar & 52 \\
Çocuklar & 48 \\
Kullanılmıyor & 40 \\
Yaşlılar & 26 \\
Herkes & 14 \\
Erkekler & 9 \\
Gençler & 6 \\
Bilgi alınamadı & 4 \\
\hline
\end{tabular}


Tablo 7. Apartman bahçelerinin genel kullanım şekli

\begin{tabular}{ll}
\hline Bahçelerin En Fazla Kullanım Şekilleri & Seçilme Sayısı (Adet) \\
\hline Oturmak & 68 \\
Oyun oynamak & 57 \\
Dinlenmek & 13 \\
Boş zaman geçirmek & 11 \\
Yeşil alan oluşturmak & 5 \\
Bakım yapmak & 2 \\
Sebze ihtiyaçlarımı karşılamak & 2 \\
Yemek yemek & 1 \\
Otopark & 7 \\
Kullanılmıyor & 40 \\
\hline
\end{tabular}

Apartman bahçelerinin mevsimlere göre ve gün içindeki kullanım yoğunluğuna ait bilgiler Tablo 8'de verilmiştir. Buna göre apartmanların bahçeleri sırasıyla en fazla yaz ve ilkbahar aylarında kullanılmaktadır. Bahçeler özellikle yazın oturma, oyun oynama vb amaçlarla, ilkbaharda da daha çok bitki yetiştirme ve bakım için kullanılmaktadır. Bahçeler gün içinde daha çok öğleden sonra (\%44) ve sabah (\%20) saatlerinde kullanılmaktadır.

Tablo 8. Isparta kent merkezindeki apartman bahçelerinin mevsimlere göre ve gün içindeki kullanımı

\begin{tabular}{ccc}
\hline Değişkenler & Verilen Cevaplar & Seçilme Sayısı \\
\hline & Yaz & 88 \\
& İlkbahar & 59 \\
Bahçenin En Fazla Kullanıldığı Mevsim & Kış & 5 \\
& Sonbahar & 6 \\
& Kullanılmıor & 41 \\
& Bilgi alınamadı & 4 \\
& Sabah & 42 \\
Bahçenin Gün İçinde En Fazla Kullanıldığı & Öğle & 8 \\
Zaman & Öğleden sonra & 91 \\
& Akşam & 18 \\
& Kullanılmıyor & 41 \\
& Bilgi alınamadı & 4 \\
\hline
\end{tabular}

Bahçenin kullanım amacı ve zamanı genel olarak değerlendirildiğinde, en fazla yaz mevsiminde ve öğleden sonra kadınların toplanarak oturmak ve çocukların oyun oynamak için kullandıkları görülmektedir. Isparta kent merkezindeki apartman bahçelerinde genellikle hayvan beslenmediği (\%91) anlaşılmıştır. Ancak nadiren farklı hayvanlara da rastlanılmıştır. Apartman bahçelerinde daha çok tavuk, dana, keçi, tavşan ve inek beslenmektedir (Şekil 4).
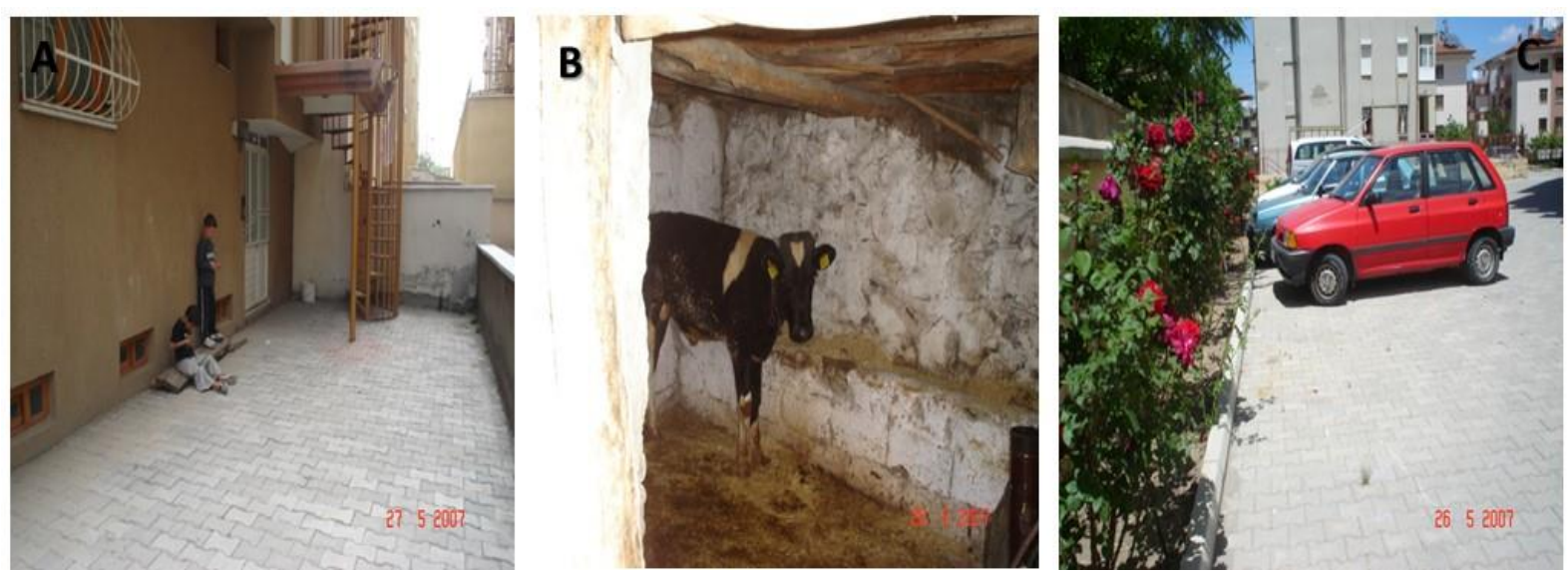

Şekil 4. Bahçelerin kullanım amaçları (A: Oturma ve oyun oynama amaçlı; B: Büyükbaş hayvan besleme amaçl1; C: Otopark amaçli) 
Yerinde ayrıntılı incelemesi yapılan 151 bahçesinde, deneklerin bahçede hayvanları gözlemleyip gözlemlemedikleri sorulduğunda, \%43'ü bahçede hayvanları gördüğünü, \%54'ü ise görmediğini bildirmiştir. Özellikle çevreleme elemanı bulunmayan veya yetersiz olan apartmanların bahçelerine dışarıdan çeşitli hayvanların girmesi kaçınılmazdır. Bahçede gözlenen hayvanlar sırasıyla kedi, köpek ve kaplumbağa olarak ifade edilmiştir. Bunun yanı sıra solucan, kirpi, salyangoz, keçi, böcekler ve kertenkelenin de apartman bahçelerinde görülen hayvanlar oldukları belirtilmiştir. Bahçelerinde dışarıdan gelen hayvanların bulunduğunu belirten 65 apartman sakinine, bahçede görülen hayvanlardan rahatsız olup olmadıkları sorulmuştur. Bunlardan \%37'si rahatsız olduğunu, \%57'si rahatsız olmadığını bildirmiştir. Bu hayvanlardan rahatsız olma nedenlerinin başında ise, hayvanların bitkilere zarar vermesi gelmektedir. Anket uygulanan apartmanların bahçeleri ile en fazla ilgilenen kişilere, apartman bahçelerini tanımlaması istendiğinde; \%21'i bahçesini güzel ve bakımlı bulurken, \%55'i orta derecede bakımlı, \%21'i ise bahçesini çirkin ve bakımsız bulduğunu belirtmiştir.

\section{Sonuç ve Öneriler}

Konut, çevresinden kopuk bir yapı, barınak olarak ele alınmamalıdır. Zira konut çevresi, konutu olduğu kadar komşuluk ve toplumsal çevreyi de içine alan geniş bir kavramdır. Aynı zamanda, insanın çevresindeki karmaşık dünyası ile sosyal ve fiziksel ilişkisini de kapsamaktadır. Bu nedenle konut ve çevresi, o alanda ikamet edenlerin ihtiyaçlarının karşılanması ve tatmin olması açısından temel bir yaşam bölgesidir. Nitelikli bir konutun çevresi; güvenli, sağlıklı, konforlu, kullanışlı, bakımlı ve anlamlı, aynı zamanda çevreye duyarlı olmalıdır. Kişilerin yaşam koşullarıyla ilgili beklentilerin arttı̆̆ı günümüzde, yaşam çevresiyle ilgili standartların da hızla yükseldiği görülmektedir.

Kent merkezindeki apartman bahçeleri, müstakil konut bahçelerinden daha büyük alana sahip olduklarından, bahçelerdeki fonksiyon ve bitkisel materyal açısından farklılık göstermektedir. Apartmanların yoğun olduğu mahallelerde kişilerin rekreasyonel ihtiyaçlarını karşılamak, aynı zamanda komşuluk ilişkilerini pekiştirmek için ortak kullanım alanları çoğunlukla bu amaca uygun olarak düzenlenmiş, ölçü, biçim, doku ve renk açısından bitkisel materyaller ile kompozisyonlar oluşturularak bahçelere hareket kazandırılmış, böylece bahçeler sakin, huzur verici mekanlar haline dönüştürülmüştür.

Günümüzde Isparta kent merkezinde kişi başına düşen yeşil alan miktarı azalmış durumdadır. Fakat konut sakinlerinin bilinçlendirilmesiyle, bahçelerinin daha düzenli planlanması, bitki türlerinin seçiminde daha doğru uygulamalar yapılmasıyla, bitkilerin fonksiyonel ve estetik özelliklerinin ön plana çıkarılması ile, bahçeli konutlarda ikamet edenlerin doğaya olan özlemleri azaltılabilir. Bu durum beraberinde kent içi yeşil alanların hem nicelik hem de nitelik yönünden artmasını sağlayacaktır.

Apartmanların bahçe kullanımlarıyla ilgili bir genelleme yapılırsa; çoğunlukla ön bahçelerde, estetik ağırlıklı bitkilerin, özellikle güzel çiçekli çalıların tercih edildiği, yan ve arka bahçelerin ise daha çok fayda bahçesi olarak ayrıldığı ve buralarda genellikle meyvesinden yararlanılan ağaçların dikildiği ve ağaç altlarında ihtiyaca göre çeşitli sebzelerin yetiştirildiği belirlenmiştir. Bunun yanı sıra bazı apartmanların arka bahçelerinde süs bitkilerine de rastlamak mümkündür. Ayrıca arka bahçelerin herhangi bir şekilde kullanımlarının söz konusu olmadığı, terk edilmişliğe bırakıldığı, gelişigüzel bitkilendirme yapıldığı hatta depo olarak kullanıldığı durumda olan bahçelere de rastlanılmaktadır.

Apartman bahçelerinde kişilerin daha önceki yaşam şekillerinin ve yerlerinin bahçeye de yansıtıldığı görülmektedir. Ayrıca apartmanlarda ikamet eden Isparta dışından gelen kişiler, bu alanlara bir dinamizm kazandırmıştır. Bu bahçelerde kullanılan bitkisel materyallerde de çeşit yönünden sınır bulunmamakta, farklı apartmanlarda farklı bitkisel materyaller yer almaktadır.

Özellikle giriş katlarında ticaret merkezi bulunan apartmanlar, bahçelerin konutta ikamet eden kişiler tarafından kullanılmasını kısıtlamaktadır. Bu da kentsel alanlarda yeşil dokunun giderek azalmasına neden olmaktadır. Bu tür apartmanlarda ikamet edenler, bitkileri bahçelerinde değil, balkonlarda veya iç mekanlarda yetiştirmektedirler.

Isparta kent merkezinde de konutların ve bahçelerinin planlanmasında çeşitli ekolojik faktörler ele alınmalıdır. Ekolojik faktörlerden özellikle iklim koşullarına dikkat edilerek, bu doğrultuda materyal seçimi yapılırsa, ileride istenmeyen sonuçlarla karşılaşılmamış olur. Bu da kişilerin materyal konusundaki bilgilerinin artmasıly, bilgilendirilmeleriyle mümkün olacaktır.

Bitkisel materyal temininde, kamu ve özel şahıslara ait fidanlıklar artan talep karşısında yetersiz kalmakta, bunun sonucunda kişiler ilçelerden veya yakın şehirlerden (özellikle Antalya) ziyaretleri sırasında çeşitli bitkiler 
getirmektedirler. Özellikle maddi durumu iyi olan kişiler tarafından getirilen pahalı, gösterişli olan bu bitkiler sıcak iklim bölgelerinde yetiştikleri için Isparta'nın sert geçen kış koşullarına dış mekânda fazla dayanamamakta, bölge ekolojisine uygun olmayan bitki türlerinin kullanımı, bazı sorunları beraberinde getirmektedir. Bu nedenle kent içi ve yakın çevresinde bulunan fidanlıkların sayısının, kalitesinin ve bitki çeşitliliğinin arttırılması gerekmektedir. Aynı zamanda bölge karakterine uygun bitkisel materyaller, yerel yönetimler tarafindan halka uygun maliyetlerde sağlanmalı, böylece kişilerin bahçelerini düzenlemeleri için farklı yerlerden bitki getirmeleri sorunu ortadan kaldırılmalı, sonuçta halkın bitki konusundaki bilgisi arttırılmalıdır. Bununla birlikte, yakın zamanda inşa edilen ya da bahçesi yeni düzenlenen konutların bahçelerinde bitki çeşitliliğinin daha fazla olduğu da ortaya çıkmıştır.

Apartman bahçelerinin gece kullanımları da düşünülerek, terk edilmişlik yaratmayacak, bazı suçların işlenmesine engel olacak şekilde tasarlanmaları, böylece kullanıcıların güvenlik unsurunu zedeleyecek uygulamalardan kaçınılması gerekmektedir.

Bitkisel tasarımda, kent ölçeğinde geçmişte var olup günümüzde fazla kullanılmayan, bölgenin iklim koşullarına uygun olan bitki türlerinin belirlenerek, kent içi apartman bahçelerinde kullanılmaları sağlanmalıdır. Apartman bahçelerinde gül kullanımının fazla olduğunun saptanmasına rağmen, Isparta'nın simgesi olması bakımından özel bir öneme sahip, Isparta ile özdeşleşen ve her firsatta Isparta'nın tanıtımında yoğun olarak kullanılan Isparta gülünün, bahçelerde kullanılmadığı görülmektedir. Süs bitkisi olarak pek kullanıma uygun olmasa da Isparta iklimine uygun, yöresel simge durumundaki bu bitkinin apartman bahçeleri ile topluma açı alanlarda (park, bahçe vb) kullanımının artırılması gerekmektedir. Ayrıca Isparta bölgesindeki doğal bitki türleri üzerine araştırmalar arttırılmalı, bu bitkilerden kentsel alanlarda yararlanma olanaklar araştırılmalıdır.

Apartman bahçelerinin düzenlenmesi konusunda, peyzaj mimarlı̆̆ meslek disiplinine gereken özen gösterilmelidir. Modern çağın bir gereği olarak belediye sınırları içindeki konut alanlarının inşaat ruhsatı verilmeden önce onaylı çevre düzenleme projesi (peyzaj projesi) de zorunlu kılınmalıdır. Yerel yönetimler tarafından apartmanlar için en güzel bahçe seçilip ödüllendirilerek kent halkının, bahçesini düzenlemeye teşvik edildiği yarışmalar geleneksel hale getirilerek, kişiler bu tür etkinliklere yönlendirilebilir.

\section{Teşekkür}

Bu çalışma, SDÜ Rektörlüğü Bilimsel Araştırma Projeleri, 1370 - D - 06 No'lu "Isparta Kent Merkezi Konut Bahçelerindeki Bitkisel Materyalin İncelenmesi Üzerine Bir Araştırma" başlıklı proje kapsamında gerçekleştirilmiş̧ir.

\section{Kaynaklar}

1. URL-1 (1993). https://www.larousse.fr/en/dictionaries/french-english, (16.03.2020).

2. URL-2 (2020). https://ispartada.gen.tr/isparta-genel-bilgiler, (22.05.2020).

3. URL-3, (2004). https://webdosya.csb.gov.tr/db/ced/icerikler/isparta_-cdr2018-20190704114736.pdf. T.C. Isparta Valiliği İl Çevre ve Orman Müdürlüğü Yayını, Isparta. (11.03.2004).

4. URL-4, (2020). https://isparta.ktb.gov.tr/TR-71025/iklim.html (22.05.2020).

5. Bakan, K., Konuk, G. (1987). Türkiye'de Kentsel Dış Mekanların Düzenlenmesi. TÜBİTAK Yapı Araştırma Enstitüsü, 106s, Ankara.

6. Gültekin, E. (1991). Bahçe ve Sanat Tarihi. PM-101. Çukurova Üniversitesi Ziraat Fakültesi Ders Kitabı No:94, Ç.Ü. Ziraat Fakültesi Ofset ve Teksir Atölyesi, Adana.

7. İnce Güney, Y. (2009). Konutta Mekânsal Organizasyon ve Toplumsal Cinsiyet: Yirminci Yüzyıl Ankara Apartmanları, Cins Cins Mekân. A. Alkan (drl.). Varlık Yayınları, İstanbul.

8. Keleş, R. (1980). Kentbilim Terimleri Sözlüğü, Türk Dil Kurumu Yayınları:474, 196s, Ankara.

9. Kuş Şahin, C. (2008). Isparta Kent Merkezi Konut Bahçelerindeki Bitkisel Materyalin İncelenmesi Üzerine Bir Araştırma. Süleyman Demirel Üniversitesi Fen Bilimleri Enstitüsü Bahçe Bitkileri Anabilim Dalı Doktora Tezi, Isparta. $287 \mathrm{~s}$.

10. Öncel, A. D. (2014). Apartman: Galata'da Yeni Bir Konut Tipi. Kitap Yayınevi, İstanbul.

11. Salbacak, S. (2019). Mütareke Dönemi İstanbul'unda Beyoğlu'nun Çok Kültürlü Yapısı ve Frej Apartmanı. International Journal of Social and Humanities Sciences, 3(1): 33-44.

12. Görgülü, T. (2016). Apartman Tipolojisinde Geçmişten Bugüne; Kira Apartmanından "Rezidans'a" Geçiş. Türkiye Bilimler Akademisi Kültür Envanteri Dergisi, Sayı 14, 165-178. 